Buana Sains Vol 18 No 2: 131 - 138, 2018

\title{
FERMENTASI BLOTONG LIMBAH PG. KREBET DAN RUMEN SAPI DALAM PRODUKSI BIOGAS
}

\author{
Pramono Sasongko dan Lorine Tantalu \\ Program Studi Teknologi Industri Pertanian, Fakultas Pertanian, Universitas \\ Tribhuwana Tunggadewi
}

\begin{abstract}
Sugar Cane Filter Cake (SGFC) is the sugar cane to sugar processing waste in Krebet Baru Sugar Factory. Utilization of this SGFC waste was limited for free soil or unprocessed fertilizer. Sugar cane filter cake is an organic waste which potential to be utilized into biogas. Biogas is anaerobic process product which consist methane as a major compound. Factors that influence biogas fermentation process were temperature, water content, fiber, total sugar and total concentration of methanogen bacteria inoculum. Natural source of methanogenic bacteria is in the contents of the cattle rumen. The aim of this study was to determine the characteristics of blotong and the effect of addition of cattle rumen on biogas fermentation from the SGFC of the Krebet Sugar Factory. The first stage of this research was Blotong characterization. The second stage was spontaneous fermentation with two treatment factors. The first factor was enhancing the contents of the cattle rumen $(5 \%)$ and without the addition of cattle rumen $(0 \%)$. The second factor is the fermentation time with 3 different levels $(20,25$ and 30 days). The results were shown that blotong had water content, fiber content, and C / $\mathrm{N}$ ratio were $10.71 \% ; 0.06 \%$; and 17 : , respectively. These results indicate the potential of the blotong as a raw material for biogas production. SGFC fermentation with the addition of $5 \%$ cattle rumen content was shown the best results compared to biogas production with pure SGFC. The highest volume and yield of biogas produced were obtained from the 30-day fermentation process with the results of $37,327 \mathrm{ml}$ of gas and $746.5 \times 10-6 \mathrm{~m}^{3} / \mathrm{kg}$. All flame tests show positive results and are proven to produce blue flames.
\end{abstract}

Keywords: Sugar Cane Filter Cake (SGFC); rumen; anaerobic fermentation; biogas; production

\section{Pendahuluan}

Blotong yang berbentuk padatan, bertemperatur tinggi, dan mengandung serat merupakan salah satu limbah dari proses pengolahan tebu menjadi gula. Dalam satu siklus produksi gula Pabrik Gula (PG) Krebet Baru dapat melakukan kegiatan giling dengan kapasitas sebesar 11.500 ton per hari dengan pembagian kapasitas produksi PG. Krebet 1 menghasilkan 6000 TCD (Ton Cane Day) atau ton per hari dan PG. Krebet Baru II sebanyak 5500 TCD. Rendemen yang dihasilkan untuk mengolah gula mencapai $6,3 \%$. Sedangkan blotong yang dihasilkan sebanyak 3.8\% atau sekitar 437 ton per hari (Sasongko dan Tantalu, 2018). Pemanfaatan limbah blotong ini hingga saat ini baru terbatas sebagai tanah urug atau pupuk tanaman gratis. 
Blotong limbah pabrik gula dapat juga dimanfaatkan sebagai pupuk organic maupun bahan tambahan untuk batu bata (Muhsin, 2011; Marwahyudi, 2013; Pakpahan, dkk., 2015). Blotong masuk dalam kategori limbah organik yang memiliki potensi untuk dapat dimanfaatkan lebih lanjut salah satunya menjadi biogas. Bahan organik memiliki potensi yang cukup besar untuk diolah menjadi biogas secara anaerobik (Agrawal, et. Al, 2009).

Biogas adalah hasil akhir dari proses anaerobik dengan komponen utama yang berupa metana $\left(\mathrm{CH}_{4}\right), \mathrm{CO}_{2}$, $\mathrm{H}_{2}, \mathrm{~N}_{2}$ dan gas lain seperti $\mathrm{H}_{2} \mathrm{~S} .1 \mathrm{~m}^{3}$ biogas memiliki volume yang setara dengan setengah kilogram gas alam cair atau setengah liter bensin atau diesel (Rahayu, dkk., 2009). Faktor-faktor yang mempengaruhi proses fermentasi biogas meliputi suhu, kadar air, serat, total gula dan total konsetrasi inokulum bakteri fermentasi penghasil metana (Wati dan Prasetyani, 2012). Fermentasi biogas dipengaruhi oleh aktifitias bakteri methanogen (pembentuk gas metan). Salah satu sumber alami dari bakteri metanogen adalah pada isi rumen sapi. Akan tetapi aktifitas bakteri dari isi rumen sapi ketika berada diluar rumen sapi belum diketahui. Oleh karena itu penelitian ini bertujuan untuk mengetahui pengaruh penambahan rumen sapi pada fermentasi biogas dari limbah blotong PG Krebet. Selain itu karakterisasi limbah blotong dari PG Krebet dilakukan untuk mendapat informasi tambahan tentang potensi limbah blotong PG Krebet sebagai bahan baku pembuatan biogas.

\section{Metode Penelitian}

Penelitian ini dilakukan dengan menggunakan bahan baku berupa Limbah blotong dari PG Krebet Bululawang Kabupaten Malang Jawa
Timur. Proses karakterisasi bahan baku dilakukan di laboratorium Kimia Universitas Tribhuwana Tunggadewi Malang dan Laboratorium Pengujian Mutu dan Keamanan Pangan Jurusan Teknologi Hasil Pertanian Universitas Brawijaya.

Penelitian ini terbagi dalam dua tahapan pelaksanaan antara lain tahap pertama adalah Karakterisasi Blotong limbah PG Krebet dengan parameter yang digunakan adalah Kadar Air, Kadar Serat, dan C/N Ratio. Tahap kedua adalah fermentasi secara spontan dengan dua factor perlakuan berbeda. Faktor pertama adalah penambah isi rumen sapi (5\%) dan tanpa penambahan rumen sapi $(0 \%)$. Faktor kedua adalah lama fermentasi dengan 3 level berbeda (20, 25 dan 30 hari). Biogas yang dihasilkan tersebut akan diuji kuantitasnya (Volume dan Rendemen) dan kualitasnya (uji nyala). Proses fermentasi akan dilakukan dalam kondisi Anaerob dalam fermentor sederhana yang dirancang dan dibangun dengan kapasitas maksimal 20 Liter.

\section{Hasil dan Pembahasan}

\section{Karakteristik Blotong}

Dalam produksi biogas berbahan baku limbah blotong dari Pabrik Gula, yaitu dari PG Krebet Bululawang, penting dilakukan karakterisasi kadar air dan kadar serat. Hasil analisa laboratorium untuk limbah blotong tersaji pada Tabel 1. Faktor utama yang mempengaruhi kualitas dari biogas adalah kadar air bahan baku (Sanjaya, dkk., 2014). Hasil analisis nilai Kadar Air dan Kadar Serat secara rata-rata menunjukkan berturut-turut sebesar $10,17 \%$ dan $0,06 \%$.

Kadar air limbah blotong tersebut menunjukkan angka cukup rendah dikarenakan saat pengambilan sudah dalam bentuk timbunan ditempat 
terbuka. PG Krebet menginformasikan bahwa blotong tersebut diletakkan ditempat terbuka hijau dengan tujuan untuk mempermudah para petani dalam pemanfaatannya sebagai pupuk organik. Semakin banyak air pada produksi biogas diketahui akan mendorong reaksi penguraian senyawa organik kompleks menjadi senyawa-senyawa sederhana yang dapat oleh mikroba penghasil gas metana secara langsung (Zuliyana, dkk., 2015). Keberadaan air juga akan mempengaruhi konsentrasi Total Solid (TS) blotong. Penurunan konsentrasi TS pada bahan baku akan meningkatkan jumlah biogas (Padang, dkk., 2011). Untuk itu, guna mengoptimalkan volume biogas yang dihasilkan dari blotong PG Krebet perlu dilakukan penambahan air. Pada penelitian ini ditambahkan air dengan komposisi blotong dan air sebesar 1:3.

Kadar serat yang terdapat pada blotong tersebut juga menunjukkan nilai yang rendah. Rendahnya aktivitas degradasi serat pada kondisi serat awal akan menurunkan volume biogas yang dihasilkan dari aktivitas mikrobaUntuk itu, diperlukan penambahan bahan yang kaya akan hemiselulosa, selulosa dan lignin (serat kasar) dengan tambahan kandungan nitrogen, fosfat dan kalium sebagai nutrien utama penghasil biogas. Alternatif bahan penambah nutrien tersebut meliputi rumen atau feses hewan ruminansia. Feses sapi memiliki kandungan hemilulosa 18,6\%, lignin
$20,2 \%$, selulosa $25,2 \%$, fosfat $1,25 \%$, nitrogen $1,67 \%$ dan kalium 0,56\%. Sedangkan rumen sapi memiliki kandugan nitrogen $9,65 \%$, serat kasar total 24, 60\%, BETN (esktrak karbohidrat tanpa nitrogen 38,40\%, kalium $1,22 \%$ dan fosfor $0,29 \%$. Kelebihan penggunaan rumen sapi adalah adanya kandungan mikroba selulolitik yang mampu mendegradasi bahan dengan kadar serat rendah (Windyasmara, dkk., 2012). Sehingga pada tahap proses pembuatan biogas dari blotong PG krebet ini akan digunakan rumen sapi sebagai nutrient tambahan.

Kadar $\mathrm{C}$, total $\mathrm{N}$, dan $\mathrm{C} / \mathrm{N}$ ratio juga memberikan dampak yang signifikan pada proses pembuatan biogas. $\mathrm{C} / \mathrm{N}$ rasio akan mempengaruhi $\mathrm{pH}$ dari bahan baku. Semakin tinggi kadar C dalam bahan akan memberikan suasana asam dan $\mathrm{pH}$ yang rendah. Kondisi tersebut cocok dan dibutuhkan untuk menghasilkan biogas. Sebaliknya jika total $\mathrm{N}$ tinggi maka akan mendorong naiknya terbentuknya gas ammonia. Terbentuknya gas ammonia akan membuat $\mathrm{pH}$ menjadi naik dan proses metanogenesis akan terhambat (Dioga, et al., 2013). Lebih lanjut, Tabel 1 menunjukkan bahwa blotong dari limbah pabrik gula Krebet memiliki $\mathrm{C} / \mathrm{N}$ rasio sebesar 17:1, dimana hal ini menunjukkan bahwa total C 17 kali lipat total $\mathrm{N}$ sehingga akan memungkinkan untuk mendapatkan $\mathrm{pH}$ bahan baku yang rendah.

Tabel 1. Karakteristik Blotong dalam tiap 100 gram bahan.

\begin{tabular}{lll}
\hline Parameter & Jumlah & Satuan \\
\hline K. Air & 10,71 & $\%$ \\
K. Serat & 0,06 & $\%$ \\
C Total & 32,34 & $\%$ \\
N Total & 1,95 & $\%$ \\
C/N ratio & $17: 1$ & \\
Total Bahan Organik & 55,94 & $\%$ \\
\hline
\end{tabular}




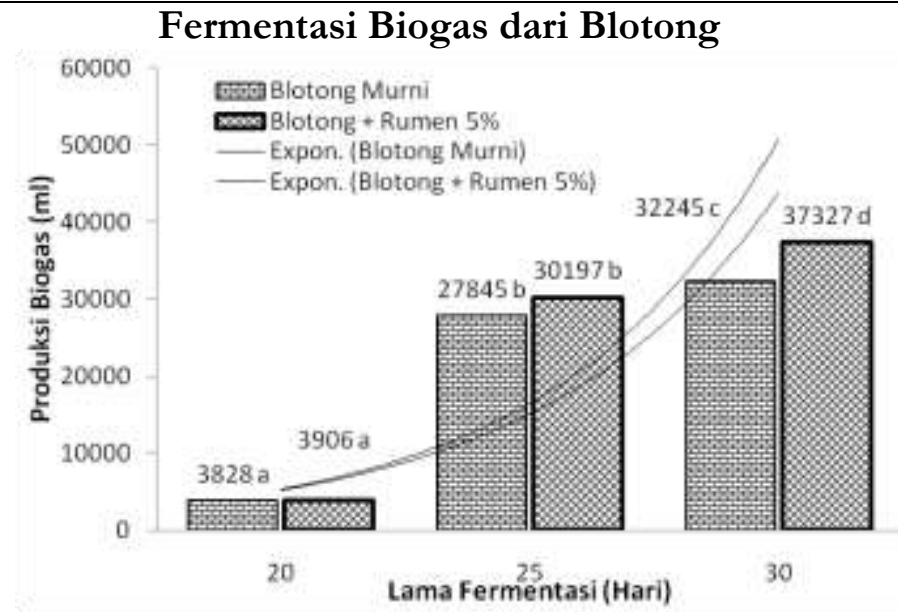

Gambar 1. Grafik volume produksi Biogas dari limbah blotong pabrik gula krebet. Notasi berbeda menunjukkan beda nyata pada $\alpha=5 \%$

Fermentasi biogas harus dilakukan didalam kondisi anaerob atau lebih dikenal dengan anaerob digestion. Produk utama yang dihasilkan dalam proses ini adalah gas metana (CH4). Gas tersebut dapat dbentuk melalui proses Metanogenesis. Menurut Dioha, et al. (2013), terdapat 4 tahapan biologis dan kimiawi kunci didalam kondisi fermentasi anaerobic untuk menhasilkan gas metana yaitu antara lain : hydrolisis, acidogenesis, acetogenesis, methanogenesis. Tahapan diatas dapat dilakukan secara simultan oleh mikroorganisme yang memfermentasi substrat baik secara spontan maupun terkontrol. Tahapan final yang membentuk gas methane $\left(\mathrm{CH}_{4}\right)$ adalah methanogenesis dimana pada saat tahapan ini terjadi pembentukan $\mathrm{CH}_{4}$ yang akanmenggunakan hydrogen, karbon dioksida $\left(\mathrm{CO}_{2}\right)$ dan asam asetat.

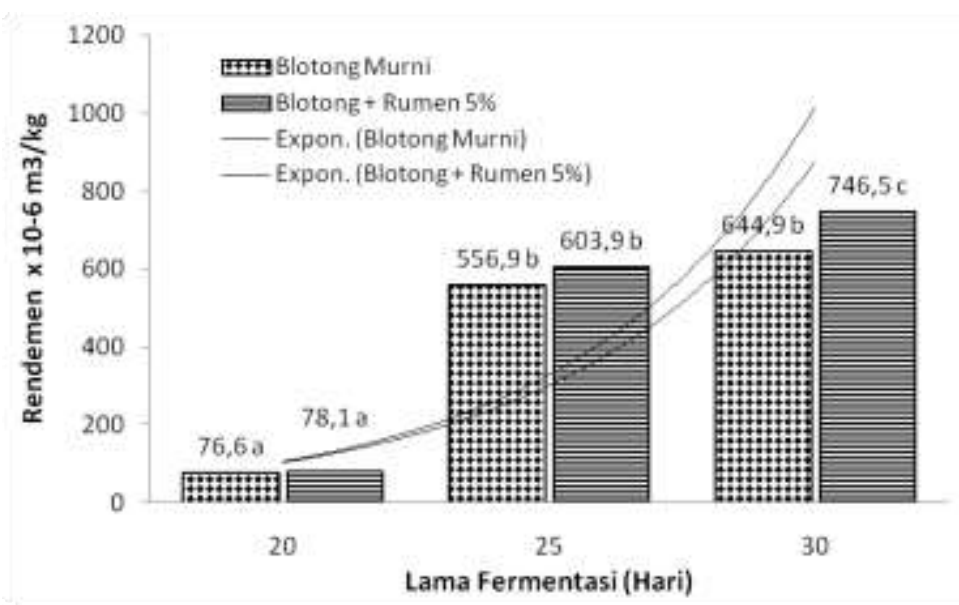

Gambar 2. Grafik rendemen biogas yang dihasilkan dari blotong limbah PG. Krebet dalam $\mathrm{m}^{3} / \mathrm{kg}$. Notasi berbeda menunjukkan beda nyata pada $\alpha=5 \%$ 
P. Sasongko dan L. Tantalu/ Buana Sains Vol 18 No 2 : 131-138

Tabel 2. Hasil Uji Nyala Biogas dari Blotong limbah PG krebet $(+)=$ Uji Nyala Posisitf, $(-)=$ Uji Nyala Negatif

\begin{tabular}{ccc}
\hline Substrat & Lama Fermentasi & Hasil uji Nyala \\
\hline \multirow{2}{*}{ Blotong Murni } & 20 & + \\
& 25 & + \\
Blotong + isi rumen sapi 5\% & 30 & + \\
& 20 & + \\
\hline
\end{tabular}

Volume produksi Biogas yang dihasilkan dari hasil fermentasi blotong yang diberi perlakuan tambahan isi rumen sapi sebanyak $5 \%$ sebagai starter mikroorganisme menunjukkan hasil yang lebih tinggi meskipun tidak berbeda nyata dengan perlakuan tanpa penambahan isi rumen sapi (Blotong murni) (Gambar 1). Kondisi tersebut nampak pada perlakuan lama fermentasi 20 dan 25 hari. Perbedaan volume produksi mulai menunjukkan perbedaan yang nyata pada perlakuan lama fermentasi 30 hari). Total akumulasi volume biogas yang tertinggi dihasilkan pada penelitian ini didapat dari perlakuan penambahan isi rumen sapi 5\% dan lama fermentasi 30 hari dengan $37.327 \mathrm{ml}$ atau 37 liter gas. Proses pengukuran volume gas yagn dihasilkan dilakukan dengan menggunakan metode Water displascement method.

Hasil dengan tren yang serupa ditunjukkan pada perhitungan rendemen (yield) produksi biogas dari limbah blotong PG Krebet ini. Rendemen tertinggi yang dihasilkan didapat dari perlakuan penambahan isi rumen sapi 5\% dan lama fermentasi 30 hari dengan angka rendemen sebesar 746,5 x 10-6 $\mathrm{m}^{3} / \mathrm{kg}$. Rendemen produksi biogas ini relative rendah jika dibandingkan pada penelitian sebelumnya yang menunjukkan rendemen biogas dari tanaman tebu dan beberapa jenis limbah lainnya adalah pada kisaran 0,28-0,7 $\mathrm{m}^{3} / \mathrm{kg}$. kemungkinan hal ini dipengaruhi dengan alat dan kondisi fermentasi yang belum sepenuhnya terkontrol. Jika dilakukan optimasi fermentasi masih dapat ditingkatkan rendemennya. Meskipun hasil rendemen menunjukkan angka yang tidak terlalu tinggi akan tetapi potensi biogas yang dihasilkan masih cukup tinggi. Hal ini dilihat dari seluruh uji nyala yang menunjukkan hasil yang positif (Tabel 2). Warna api yang dihasilkan adalah biru terang yang hal ini dapat dijadikan acuan bahwa api yang dihasilkan merupakan hasil pembakaran dari gas metana (Gambar 3). Untuk dapat memastikan persentase gas metana yang dihasilkan masih perlu dilakukan penelitian lebih lanjut untuk mengetahui profil gas menggunakan metode yang lebih akurat seperti penggunaan GC-MS.

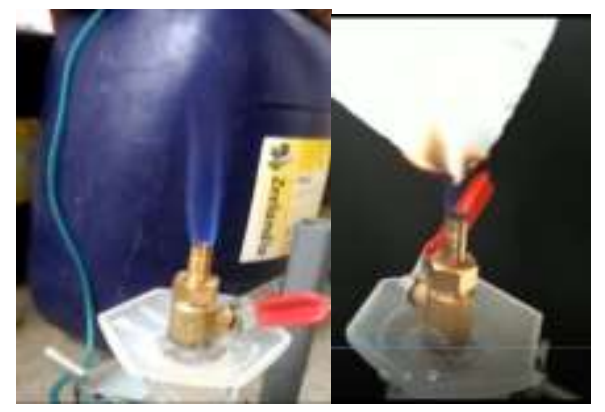

Gambar 3. Foto Uji Nyala Biogas dari Blotong limbah PG Krebet dan Rumen sapi 
P. Sasongko dan L. Tantalu/ Buana Sains Vol 18 No 2 : 131-138

Hasil yang didapat menunjukkan hasil produksi biogas yang relatif rendah. Hal ini kemungkinan besar disebabkan oleh penggunaan bioreaktor atau fermentor dengan desain yang belum bisa memberikan kondisi optimum yang diperlukan dalam fermentasi biogas. Pada penelitian sebelumnya hasil produksi biogas dan gas metana dari limbah blotong menunjukkan hasil yang baik karena menggunakan bioreactor atau fermentor dengan Continous Stirrer Tank Reactor system atau CSTR (Janke et al, 2015). Sedangkan pada penelitian ini bioreaktor yang dikembangkan belum memiliki system pengaduk otomatis tersebut. Tanpa ada nya system pengaduk tersebut biogas yang diproduksi di bagian bawah fermentor tidak dapat di rilis keluar dan tertahan di dalam slurry blotong yang difermentasi. Kondisi tersebut menyebabkan laju pelepasan gas menuju bagian head space dari fermentor berjalan sangat lambat dan produksi biogas pun menjadi terhambat.

\section{Kesimpulan}

Blotong limbah Pabrik Gula Krebet memiliki karakteristik dasar yang menunjukkan potensi sebagai bahan baku produksi biogas. Fermentasi Blotong dengan penambahan isi rumen sapi sebanyak $5 \%$ memberikan hasil terbaik dibandingkan produksi biogas dengan blotong murni. Volume dan rendemen biogas yang dihasilkan paling tinggi didapat dari lama proses fermentasi 30 hari dengan hasil $37.327 \mathrm{ml}$ gas dan $746,5 \times 10^{-6} \mathrm{~m}^{3} / \mathrm{kg}$. Seluruh uji nyala menunjukkan hasil yang positif dan terbukti dapat menghasilkan nyala api yang berwarna biru. Blotong yang didapat dari limbah PG Krebet memiliki potensi yang sangat baik untuk dapat diolah menjadi sumber energy terbarukan yaitu biogas yang dapat memberikan peningkatakn efisiensi dari sisi ketersediaan energy untuk pabrik.

\section{Ucapan Terima Kasih}

Ucapan terima kasih diberikan kepada Direktorat Riset dan Pengabdian Masyarakat (DRPM), Direktorat Jenderal Penguatan Riset dan Pengembangan Kementrian Riset, Teknologi dan Pendidikan Tinggi yang telah mendanai kegiatan Penelitian Dosen Pemula Tahun Anggaran 2018 dengan judul Pemanfaatan Limbah Blotong PG Krebet Sebagai Bahan Baku Produksi Biogas Dalam Upaya Pengembangan Industri Terintegrasi. Ucapan terima kasih diucapkan pula kepada Pabrik Gula (PG.) Krebet Baru yang telah bersedia menjalin kerjasama dengan Program Studi Teknologi Industri Pertanian khususnya peneliti, dalam penyediaan sumber utama penelitian yaitu limbah blotong. Tak lupa diucapkan terima kasih kepada Universitas Tribhuwana Tunggadewi, khususnya unit LPPM yang terus membimbing dan mendampingi hingga terselesaikannya kegiatan ini.

\section{Daftar Pustaka}

Agrawal et al. 2009. Biogas from Pressmud. Journal of Mechanical and Civil Engineering (IOSR-JMCE). ISSN: 2278-1684, PP: 37-41.

Andreas Felix S., Paramitha S.B.U., dan Ikhsan D., 2012, Pembuatan Biogas Dari Sampah Sayuran, Jurnal Teknologi Kimia dan Industri, Vol. 1 No.1 hal 103-108.

Dioha., I.J., Ikeme., C.H., Nafi'u, T., So., N.I. Soba, and Yusuf., M.B.S. 2013. Effect of Carbon to Nitrogen Ratio on Biogas production. International research Journal of natural Sciences. Vol 1 no 3, pp1-10, September 2013

Janke, L., Leite, A., Nikolausz, M., Schimdt, T., Liebetrau, J., Nelles, M., and Stinner, W. 2015. Biogas Production from sugarcane waste: Assessment on Kinetic Challenges for 
P. Sasongko dan L. Tantalu/ Buana Sains Vol 18 No 2 : 131-138

Process Designing. International Journal of

Molecular Sciences. ISSN 1422-0067. Vol 16, 20685-20703.

Marwahyudi. 2013. Mengurangi Bahan Baku Tanah Sawah Dengan Menambah Limbah Blotong Pada Pembuatan Batu Bata Ramah Lingkungan. Jurnal Eco Rekayasa. Vol. 9, No. 2, pp: 109115.

Muhsin, A. 2011. Mengurangi Bahan Baku Tanah Sawah dengan Menambah Limbah Blotong pada Pembuatan Batu Bata Ramah Lingkungan. Publikasi Jurnal Eco Rekayasa, Vol. 9, No. 2. Hal 109-115.

Padang, Y.A., Nurcahyati, dan Suhudi. 2011. Meningkatkan Kualitas Biogas dengan Penambahan Gula. Jurnal Teknik Rekayasa, Vol. 12, No. 1, hal: 53-62

Pakpahan, A.F., Rohmah, A., Panggabean, S. 2015. Pemanfaatan Blotong Tebu untuk Mengurangi Pemakaian Semen Pada Pembuatan Batako. Jurnal Rekayasa Pangan dan Pertanian, Vol. 3, No. 4. Hal. 496 - 502

Rahayu, S., D. Purwaningsih dan Pujianto. 2009. Pemanfaatan Kotoran Ternak Sapi Sebagai Sumber Energi Alternatif Ramah Lingkungan Beserta Aspek Sosio Kulturalnya. Jurnal INOTEK, Vol. 13 No. 2.

Sanjaya, D., Haryanto, A., dan Tamrin. 2014. Produksi Biogas dari Campuran Kotoran Sapi dengan Kotoran Ayam. Jurnal Teknik Pertanian Lampung, Vol. 4, No. 2, hal: 127-136.

Sasongko, P. dan Tantalu, L. 2018. Potensi Limbah Blotong PG. Krebet Sebagai Bahan Baku Produksi Biogas dalam Upaya Pengembangan Industri Terintegrasi. Prosiding Seminar Nasional Teknologi Industri,
Lingkungan dan Infrastruktur (SENTIKUIN) 2018 ISSN : 26222744 (print), ISSN : 2622-9730 (online)

Wati, D.S. dan R.D. Prasetyani. 2012. Pembuatan Biogas Dari Limbah Cair Industri Bioetanol Melalui Proses Anaerob. Jurusan Teknik Kimia, Fakultas Teknik, Universitas Diponegoro.

Windyasmara, L., Pertiwiningrum, A., dan Yusiati, L.M. Pengaruh Jenis Kotoran Ternak Sebagai Substrat dengan Penambahan Serasah Daun Jati (Tectona grandis) Terhadap Karakteristik Biogas pada Proses Fermentasi. Buletin Peternakan, Vol. 36 No. 1, hal: 40-47. Februari 2012

Zuliyana, Wirawan, S.K., Budhijanto, W., dan Cahyono, R.B. 2015. Pengaruh Kadar Air Umpan dan Rasio $\mathrm{C} / \mathrm{N}$ pada Produksi Biogas dari Sampah Organik Pasar. Jurnal Rekayasa Proses, Vol. 9, No. 1, hal: 22-27. 
